\title{
THE MANAGEMENT OF RECURRENT APHTHOUS STOMATITIS WITH GASTROINTESTINAL DISEASE ASSOCIATED WITH HELICOBACTER PYLORI. (Case Report)
}

\author{
Solva Yuditha \\ Department of Oral Medicine FKG UPDM(B) Jakarta
}

\begin{abstract}
ABSTRAK
Latar belakang: Stomatitis Aftosa Rekuren (SAR) merupakan penyakit rongga mulut kronik yang berulang dengan etiopatogenesis yang belum diketahui pasti dan modalitas perawatan yang bermacam-macam. Tujuan: membahas penatalaksanaan pasien dengan SAR dan penyakit saluran pencernaan berkaitan dengan Helicobacter pylori. Kasus: pasien perempuan usia 19 tahun mengalami ulser berulang tiga kali dalam sebulan selama 2 tahun lalu dengan riwayat keluarga disangkal. Pasien menderita gastritis kronik yang disebabkan oleh Helicobacter pylori. Hasil pemeriksaan laboratorium menunjukkan nilai Hb dan MCV yang normal, MCH dan MCHC yang rendah, nilai leukosit yang tinggi. Pemeriksaan intraoral kunjungan pertama ditemukan ulser-ulser bulat, batas kemerahan, dasar kekuningan, ukuran kurang dari 10 mm di mukosa bukal dan 1 mm di mukosa labial bawah. Seminggu kemudian, ulser-ulser ini sembuh namun timbul ulser baru di gingiva dan mukosa bukal kiri. Diagnosis klinis lesi ini adalah SAR minor. Penatalaksanaan Kasus: setelah pemeriksaan dan konsultasi dengan dokter ahli gastroenterologi, instruksi meningkatkan kebersihan mulut untuk menghilangkan H.pylori dan mencegah reinfeksi, berkumur Klorheksidin glukonat 0,2\%2x sehari. Obat kumur Tetrasiklin 3x sehari selama 3 hari dan multivitamin mengandung vitamin B1,B6 dan B12 peroral selama 10 hari. Kesimpulan: faktor predisposisi terjadinya SAR harus ditentukan untuk mengurangi rekurensi SAR. Eliminasi Helicobacter pylori akan meningkatkan penyembuhan SAR.
\end{abstract}

Kata kunci: SAR, Helicobacter pylori, Obat Kumur Clorheksidin Glukonat 0,2\%, Obat kumur Tetrasiklin

\begin{abstract}
Backgorund: Recurrent aphthous stomatitis (RAS) is a chronic remitting oral disease with uncertain etiopathogenesis and many treatment modalities. Purpose: to discuss the management of patient with RAS and gastrointestinal diseases associated with Helicobacter pylori. Case: A 19 year old female patient experienced recurrent ulcers three times a month and has lasted since two years ago with no family history of recurrent ulcers. She also had chronic gastritis caused by Helicobacter pylori. Laboratory examinations showed normal value of Hemoglobin and MCV, low value of MCH and MCHC and high leukosit count. Intra oral examination on first visit showed well rounded ulcers, erythematous margin and yellowish floor, less then $10 \mathrm{~mm}$ on left buccal mucosa and $1 \mathrm{~mm}$ on lower labial mucosa. One week after, the ulcers on left buccal mucosa and lower labial mucosa were healed but new ulcers were found on right mandibula gingiva and left buccal mucosa with same previous RAS clinical manifestations. The clinical diagnosis was minor RAS. Case management: The patient was advised to increase oral hygiene in order to eradicate Helicobacter pylori and avoid gastrointestinal reinfection and use Chlorhexidine Gluconate $0.2 \%$ oral rinse twice daily.Tetracycline oral rinse was added three times a day for three days and multivitamins contains vitamin B1,B6, and B12 per oral once daily for 10 days. Refferal to Gastroenterologist is needed to eliminate Helicobacter pylori. Conclusion: It is important to determine the predisposing factors of RAS in order to decrease recurrence of RAS. Elimination of Helicobacter pylori will improve the healing of ulcers.
\end{abstract}

Key words: RAS, Helicobacter pylori, 0.2\% Chlorhexidine Gluconate oral rinse, Tetracycline oral rinse

\section{INTRODUCTION}

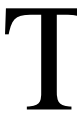

he Recurrent Aphthous Stomatitis (RAS) is a periodic painful oral disease occuring in up to $50 \%$ of the general population. ${ }^{1}$ The precise etiology of RAS is still unclear but many various factors influence such as genetics, immunological factors, microorganisms, local trauma, stress, hormone, food hypersensitivity and nutrition. ${ }^{1,2,3}$ These lesions are 
classified according to the size, site, amount of ulcers, peek of onset and pattern of the healing ulcers into three groups : minor, major and herpetiform lesions. ${ }^{3,4}$

Gastritis is an inflammation of the stomach or the duodenum lining. ${ }^{5}$ The prevalence of peptic ulcer disease has been decreased because of the widespread use of antacids, Histamine antagonists and proton pump inhibitors. ${ }^{4,5}$ Many things can cause gastritis. Most often the cause is infection with the same bacteria Helicobacter pylori - that causes stomach ulcers. In some cases, the stomach lining may be "eaten away," leading to sores (peptic ulcers) in the stomach or first part of the small intestine. Gastritis can occur suddenly (acute gastritis) or gradually (chronic gastritis). In most cases, gastritis does not permanently damage the stomach lining. ${ }^{5}$

Helicobacter pylori is a microaerophilic, Gramnegative spiral bacillus ${ }^{4,6,7}$ which is an important human pathogen associated with the etiology of chronic gastritis, peptic ulcer, gastric cancer, and mucosaassociated lymphoid tissue lymphoma and has been designated as a Group 1 Carcinogen by the International Agency for Research on Cancer of the World Health Organization (WHO) ${ }^{6,8,9}$ In addition to gastrointestinal diseases, recent data seem to suggest a possible association of this microorganism with other conditions, such as recurrent aphthous stomatitis, anemia, altered serum levels of lipoproteins, and coronary atherosclerosis. ${ }^{6,8}$

The uncertain nature of the pathogenesis of RAS is reflected in the variety of treatment modalities such as use of the protective emollient, topical anesthetic, topical and systemic steroid and other drugs and none of which is uniformly successful. ${ }^{10}$ In this case report, we discussed oral management of RAS with chronic gastritis caused by Helicobacter pylori.

\section{CASE REPORT}

A 19 years old female college student came to Oral Medicine Clinic of Rumah Sakit Gigi Mulut at Faculty of Dentistry Universitas Prof. Dr. Moestopo (Beragama) with chief complaint painful ulcers on lower lip and right cheek since 3 days before. She usually had recurrent ulcers three times a month and this has lasted since two years ago. She was also diagnosed dyspepsia due to chronic gastritis caused by $\mathrm{H}$. pylori since 2 years ago and had been hospitalized in November 2012. There was no family history of RAS. Laboratory examinations showed normal value of Hemoglobin and Mean Cospuscular Volume (MCV) although in lower borderline, low value of Mean Cospuscular Hemoglobin (MCH) and Mean Cospuscular Hemoglobin Consentration (MCHC) and high leukosit count.(see table 1)

Clinical manifestations showed well rounded ulcers, erythematous margin and yellowish floor, $3 \mathrm{~mm}$ on right buccal mucosa and $1 \mathrm{~mm}$ on lower labial mucosa and also dental plaque and calculus (Figure 1). We instructed the patient to increase her oral hygiene

by using Chlorhexidine Gluconate $0.2 \%$ oral rinse twice daily and removing dental plaque and calculus by a Periodontist. The diagnosis was Minor Recurrent Aphthous Stomatitis. At the second visit one week after, ulcers on left buccal mucosa and lower labial mucosa were healed but new ulcers were found on right mandibula gingiva and left buccal mucosa with the same previous RAS clinical manifestations (Figure 2).

TABLE 1. Full Blood Count Examination

\begin{tabular}{l|c|c|c}
\hline Hematologic (Unit) & Score (Normal range) & Hematologic (units) & Score (Normal Range) \\
\hline $\mathrm{Hb}(\mathrm{g} / \mathrm{dL})$ & $12.1(12-16)$ & Erythrocytes $\left(10^{\wedge} 6 / \mathrm{\mu L}\right)$ & $4.65(4.2-5.4)$ \\
Leukocyte $\left(\mathbf{1 0}{ }^{\wedge} \mathrm{LL}\right)$ & $9.7(4.8-10.8)$ & ESR $(\mathrm{mm} / \mathrm{hour})$ & $25(0-20)$ \\
Basophils (\%) & $0(0-1)$ & $\mathrm{Ht}(\%)$ & $37.3(37.0-47.0)$ \\
Eosinophils (\%) & $3(2-4)$ & $\mathrm{MCV}(\mathrm{fL})$ & $80.2(79-99)$ \\
Neutrophils (\%) & $63(50-70)$ & $\mathrm{MCH}(\mathrm{pg})$ & $26(27-31)$ \\
Lymphocytes (\%) & $26(25-40)$ & $\mathrm{MCHC}(\mathrm{g} / \mathrm{dL})$ & $32.4(33-37)$ \\
Monocytes (\%) & $8(2-8)$ & Platelets $\left(10^{\wedge} 3 / \mu \mathrm{L}\right)$ & $348(150-450)$ \\
\hline \multicolumn{4}{|r}{}
\end{tabular}

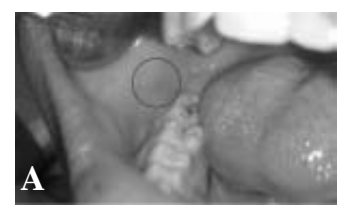

FIGGURE 1.

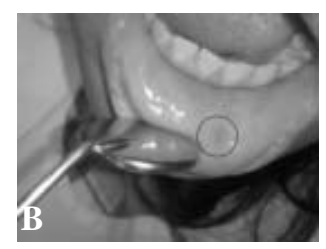

Well rounded ulcers, erythematous margin and yellowish floor, $3 \mathrm{~mm}$ across on buccal mucosa (A) and $1 \mathrm{~mm}$ on lower labial mucosa and also dental plaque and calculus (B).

Chlorhexidine Gluconate $0.2 \%$ oral rinse was still given, Tetracycline oral rinse was also given three times a day for three days and multivitamins contains vitamin B1,B6, and B12 per oral once daily for 10 days. For the next two weeks, no ulcers were found, but when she started to study, while working part time, she got exhausted, new ulcers were found on non keratinezed mucosa (Figure 3)
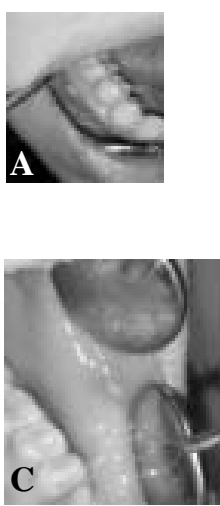
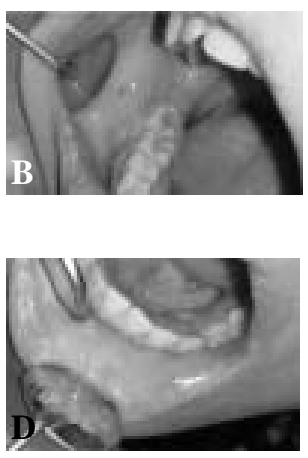

FIGGURE 2 .

Well rounded ulcers, erythematous margin and yellowish floor $4 \mathrm{~mm}$ on right mandible gingiva (a) and $3 \mathrm{~mm}$ on left buccal mucosa (c), healed ulcers (b,d) 

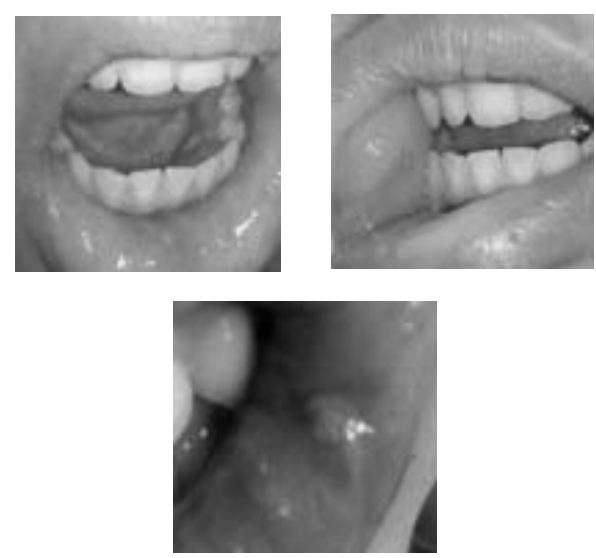

FIGGURE 3.

Well circumsribed ulcers less than 10 mm,with erythematous margin on lower labial mucosa (g), right buccal mucosa (h), and left lower labial mucosa (i).

The medications which patient consumed consist of antacids, antireflux agent antiulcerant (Pantoprazole, Sucralfate and Strocain P), GIT regulators, antiflatulents and anti inflammatory (Domperidone). At the third visit, the gastroenterologist had stop all the medication and only gave Strocain $\mathrm{P}$ and Sucralfate, only consumed if there is a symptoms of gastritis. A Periodic consultation with the gastroenterologist is a mandatory in order to prevent reinfection and eliminate H.pylori from the gastrointestinal tract.

\section{DISCUSSION}

Recurrent Aphthous Stomatitis is a chronic and inflammatory disease of oral mucosa, usually found on unkeratinized attached oral mucosa of lips, cheek and tongue, occasionally on gingival mucosa and heal spontaneously. ${ }^{2}$ It is characterized by recurring oral ulcers ${ }^{10}$ and the peak period of RAS is in the second decade with the first episode in childhood. ${ }^{2}$ All of these conditions are presented in our patient.

The patient had H.pylori infection lead to chronic gastritis with dyspepsia since 2012. Some studies showed bacterial antigens such as H.pylori have the potential factors to modify the immune response and to invoke RAS. ${ }^{7}$ The serum level of antibody against H.pylori is elevated and Tas et al confirm the advantage effect of H.pylori eradication in patients with SAR. ${ }^{4}$ Direct damage of surface epithelial cells or release of pro-inflammatory mediators after interaction with $H$. pylori initially,leading to stimulation of an immune response and release of cytokines and oxygen radicals. Extracellular product of of $H$. pylori and bacteremia will cause local and systemic immune response. Helicobacter pylori can multiply in macrophages, dendritic cells and epithelial cells. ${ }^{7}$ After the elimination of $H$.pylori, the serum vitamin B12 is increased. ${ }^{2,4}$ Deficiency of vitamin B12 lead to suppression of the cell mediated immunity and changes in the epithelium of tongue and buccal mucosa. Serum B12 is important for the synthesis of DNA and these conditions could lead to mucosal bleeding and glossitis.

Although $H$. pylori may be detected in the stomach of approximately half of the world's population, the mechanisms of transmission of the microorganism from individual to individual are still being debated. The possible routes of transmission of $H$. pylori include iatrogenic, fecal-oral, oral-oral, and through food and water. ${ }^{6,8}$ In this regard, it is noteworthy that transmission of $\mathrm{H}$. pylori between mother and child takes place in most instances around early childhood at a similar window of infectivity when certain oral microorganisms, such as mutans streptococci, which require the presence of teeth as a habitat, start to colonize the oral cavity. ${ }^{11}$

H. pylori exists in two different morphological forms, spiral and coccoid. The coccoid form is considered a degenerative or dead form of $H$. pylori, and its role in transmission of disease is negligible. There is ongoing debate about its virulence and transformation. Although the coccoid form of $H$. pylori is metabolically active, more resistant to antibiotics, and can not be cultured in vitro. The organism has been reported to be present in soil samples in public playgrounds. However, no extra-gastric reservoirs of $H$. pylori have been clearly demonstrated, and although organisms resembling $H$. pylori may be detected in other animals, none except non-human primates and cats harbor $H$. pylori. Infections by Helicobacter species (H. heilmannii and $H$. felis) have been reported in dogs and cats. ${ }^{6}$

Many possible routes of transmission of $H$. pylori such as through orally ${ }^{6}$ and studies in developed countries showed that neither dental plaques and dentures are permanent reservoir for H.pylori and can be found on buccal mucosa, deep muscle layer of tongue, normal tonsil and adenoid tissue. Meanwhile in developing countries revealed a high prevalence of $H$. pylory. in dental plaques and saliva, though elsewhere the culture of bacterium or its DNA analysis by polymerase chain reaction (PCR) in the material obtained from oral cavity were not successful 9,12 although we did not examine dental plaque by PCR to confirm that dental plaque are reservoir for H.pylori.

The oral cavity is permanent reservoir of H.pylory and has a clear association with gastro esophageal infection. ${ }^{4,9,12}$ However, the question still persists as to whether the oral cavity is a major extragastric reservoir for $H$. pylori or harbors the organism only transiently. If the oral cavity, particularly the dental plaque, serves as an extra-gastric reservoir of $H$. pylori, it may have a clear association with gastroesophageal infection $^{9}$ and also serious implications regarding the treatment of $H$. pylori infection ${ }^{6}$ leading to gastric reinfection. ${ }^{9}$ Poor periodontal health characterized by gingivitis and chronic periodontitis may be associated with $\mathrm{H}$. pylori infection and considered as a potential reservoir of these bacteria. Professional plaque removal and oral hygiene procedures should be performed along 
with eradication strategies of $H$. pylori. ${ }^{9}$

Poor salivary secretion may contribute to the deposition of dental plaque because of the loss of natural cleansing of the oral cavity. On the other hand, low salivary secretion apply favorable environment for the growth of bacteria including $H$. pylori. Namiot et al. reported that low salivary secretion may contribute to the decrease in efficacy of $\mathrm{H}$. pylori eradication from the stomach, especially in patients with certain drug regimens including omeprazole, amoxicillin and tinidazole. They compared the effect of two different drug regimens on the eradication of $\mathrm{H}$. pylori regarding salivary flow rate and the patient has normal salivary flow rate. The role of saliva in maintaining oral health is clear. There are possible important factors in the elimination of $\mathrm{H}$. pylori from the oral cavity including the cleansing effect of saliva, salivary antibacterial substances against H. pylori such as specific IgA, IgG, lactoferrin and EGF as well as salivary secretion of antiH. pylori antibiotics. ${ }^{9}$ Although side effects of proton pump inhibitors such as Omeprazole is reduction of salivary flow rate. ${ }^{13}$

One of the suggested mechanisms of reinfection is the possible re-colonization from dental plaque. A few studies have also suggested that periodontal disease may also favor colonization of dental plaque by $H$. pylori. ${ }^{6}$ This is on account of the fact that treatment of $H$. pylori infection usually involves administration of systemic antibiotics in combination with other drugs, and dental plaque, being a microbial biofilm, provides protection for the resident microorganisms from systemically administered antimicrobial agents. Despite the current treatment regimens that lead to successful management of $H$. pylori-positive chronic gastritis, the re-infection rate is relatively high. ${ }^{6}$ It would be important as a dentist to increase oral hygiene and determine the predisposing factors when treat RAS patient with gastrointestinal disease especially infection of H.pylori incorcurrent with consultation and treatment with the gastroenterologist.

Tetracycline acts as an anti-inflammatory agent via non-antimicrobial actions by many actions such as down regulations of pro-inflammatory cytokines, inhibit matrix metalloproteinases (MMPs), synthesis of prostaglandin, release of nitric oxide and activation of caspase. ${ }^{13}$ Tetracycline also has anti-collagenolytic properties an enhancement of collagen synthesis. ${ }^{14}$

\section{CONCLUSION}

It is important to determine the predisposing factors of RAS in order to decrease recurrence of RAS. Hematologic disorders must be treated, elimination of H.pylori and improvement of oral hygiene will advance the healing of ulcers.

\section{REFERENCES}

1. Khan NF, Saeed M, Chaudhary S, Ghafoor F. Journal of the College of Physicians and Surgeons Pakistan 2013, Vol. 23 (2): 124-127

2. Slebioda Z, Szponar E. Etiopathogenesis of Recurrent Aphthous Stomatitis and the Role of Immunologic Aspects: Literature Review. Arch.Immunol.Ther.Exp. (2014) 62:205-15

3. Greenberg MS, Glick M, Ship JA. Burket’s Oral Medicine 11 th ed. 2008. BC Decker inc. India 57-60. 13.

4. $\mathrm{Ta}^{\mathrm{O}} \mathrm{DA}$, Yakar T, Sakalli H, Serin E. Impact of Helicobacter pylori on the clinical course of recurrent aphthous stomatitis. J Oral Pathol Med (2013) 42: 89-94

5. Gastritis University of Maryland Medical Center http:// umm.edu/health/medical/altmed/condition/ gastritis\#ixzz3CPbdyE00 University of Maryland Medical Center

6. Anand PA, Kamath KP, Anil S.Role of dental plaque, saliva and periodontal disease in Helicobacter pylori infection WJG 20th Anniversary Special Issues (6): Helicobacter pylori. World J Gastroenterol 2014 May 21; 20(19): 5639-5653

7. Irani S, Esfahani AM, Zerehpoush FB.Detection of Helicobacter pylori in Oral Lesions J Dent Res Dent Clin Dent Prospect 2013;7(4):230-237 | doi: 10.5681/ joddd.2013.037

8. Zou Q-H, Li R-Q. Helicobacter pylori in the oral cavity and gastric mucosa: a meta analysis. J Oral Pathol Med (2011) 40: 317-24.

9. Burgan SZ, Sawair FA, amarin ZO. Hematologic status in patients with recurrent aphthous Stomatitis in Jordan. Saudi Med J (2006) 27 (3): 381-4

10. Bürgers R, Schneider-Brachert W, Reischl U, Behr A, Hiller K-A, Lehn N, Schmalz G, Ruhl S. Helicobacter pylori in human oral cavity and stomach. Eur J Oral Sci 2008; 116: 297-304.

11. Vahedi M, AR. Khalilian AR, Abdollahzadeh Sh, Shafiei N. Saliva Secretion and Efficacy of Helicobacter Pylori Eradication in Peptic Ulcer Patients. Journal of Dentistry, Tehran University of Medical Sciences, Tehran, Iran (2011; Vol. 8, No.4)

12. Pytko-Polonczyk J, Konturek SJ, Karczewska E, Bielañski W, Kaczmarczyk-Stachowska A. Oral cavity as permanent reservoir of Helicobacter pylori and potential source of reinfection. J Physiol Pharmacol. 1996 Mar;47(1):121-9.

13. Scully C. (2010) Oral and Maxillofacial Medicine The Basis of diagnosis and treatment (2nd ed.). Elsevier. 79

14. Weinberg MA, Bral M. Tetracycline and its analogues: a therapeutic paradigm in periodontal disease. Crit Rev Oral Biol Med 9(3):322-332 (1998) 